\title{
RECENT ANTHOLOGIES AND RESOURCES
}

\author{
Compiled by Adam Gregerman, Review Editor
}

Duchesne, Jean, ed. Cardinal Jean-Marie Lustiger on Christians and Jews. Mahwah, NJ: Paulist, 2010.

Contains speeches by and interviews with Cardinal Lustiger, archbishop of Paris and a convert to Catholicism from Judaism.

Fisher, Eugene J., and Leon Klenicki, eds. The Saint for Shalom: How Pope John Paul II Transformed Catholic-Jewish Relations. New York: Crossroad, 2011.

A collection of Pope John Paul II's statements on Judaism and Jewish-Catholic relations throughout his entire papacy, 1979-2005.

Fisher, Eugene J., ed. Memoria Futuri: Catholic-Jewish Dialogue Yesterday, Today, and Tomorrow; Texts and Addresses of Cardinal William H. Keeler. Mahwah, NJ: Paulist, 2012.

A collection of statements by Cardinal Keeler, Archbishop of Baltimore from 1989-2007 and moderator for Catholic-Jewish relations for the United States Conference of Catholic Bishops.

Sherman, Franklin, ed. Volume One: The Road to Reconciliation (1945-1985), Bridges: Documents of the Christian-Jewish Dialogue. New York and Mahwah: Paulist, 2011.

An extensive collection of texts from religious bodies and groups of scholars and clergy from 1945-1985, organized in five parts (Protestant Statements, Roman Catholic State ments, Ecumenical [Christian] Statements, Joint Jewish-Christian Statements, and Jewish Viewpoints). Introductions by Alice L. Eckardt, Philip A. Cunningham, and Michael S. Kogan. 